\title{
Designing IQMM as a Maturity Model for Information Quality Management
}

\author{
Angelina Prima Kurniati \\ Telkom Institute of \\ Technology, Bandung, \\ Indonesia
}

apk@ittelkom.ac.id

\author{
Kridanto Surendro \\ Bandung Institute of \\ Technology, Bandung, \\ Indonesia
}

endro@informatika.org

\begin{abstract}
Every organization requires data and information to run its business and support decision making. These data and information can be obtained from many sources, internal or external organization. Wherever they come from, data and information should be free from any errors and defects to make the business run well and the decision taken from them qualified. Assuring data and information quality is not easy because data and information nowadays are easier to obtain while data repositories tend to be cheaper. Organizations rely on Information Technology to handle this issue. Technology being used should definitely be reliable to assure that error-free data and information are available whenever they are needed. We propose a model to manage and incrementally improve information quality management processes in organizations, called IQMM (Information Quality Maturity Model), which is built using COBIT 4.1 maturity model approach. Organizations can use this model anytime to understand current condition of their information quality management and to provide improvement plans to take.
\end{abstract}

Keywords: Maturity model, information, information quality, error-free data, COBIT 4.1

\section{Introduction}

Nowadays, organizations run their business by taking advantage of Information Technology to process data and information they are needed in daily activities and decision making processes. To keep activities and processes run well, organizations should have a strategy in assuring data and information quality.

In fact, assuring data and information quality is not an easy task. Some problems occur in planning, obtaining, storing and saving, maintaining, applying, and even in disposal phase of information life cycle (Al-Hakim, 2007b). Organizations have to find the problems and fix it, which is not an easy task, too.

Material published as part of this publication, either on-line or in print, is copyrighted by the Informing Science Institute. Permission to make digital or paper copy of part or all of these works for personal or classroom use is granted without fee provided that the copies are not made or distributed for profit or commercial advantage AND that copies 1) bear this notice in full and 2) give the full citation on the first page. It is permissible to abstract these works so long as credit is given. To copy in all other cases or to republish or to post on a server or to redistribute to lists requires specific permission and payment of a fee. Contact Publisher@InformingScience.org to request redistribution permission.
Some methods are proposed to handle that need correctively: organization having problems in its information management processes can apply the method to identify the cause of the problem and the corrective plan to do. It would be better for organization to understand their current condition of information management processes and preventively keep those processes in a good quality. 
We propose a new method for assuring quality of information management processes, called Information Quality Maturity Model (IQMM), which is built using COBIT 4.1 approach (IT Governance Institute, 2007). IQMM can be used as guidance for organizations to understand their current and targeted maturity level of their information management processes. The gap between current and targeted maturity level identified can be used to establish the improvement strategies and priorities.

\section{Material and Methods}

\section{Information}

Information can be defined by understanding the relationship between data, information and knowledge. Data are often viewed as simple facts. When data are put into a context and combined within some structure, information emerges. When information is given meaning by being interpreted, information becomes knowledge (Wang, Pierce, Madnick, \& Fisher, 2005).

This definition can be illustrated as in Figure 1.

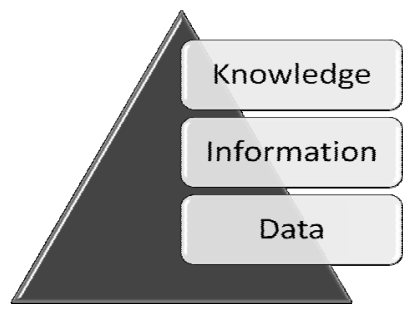

Figure 1. Definition of Information

Ballou, Wang, Pazer, and Tayi (1998) and Huang, Lee, and Wang (1999) define information as a product of information manufacturing system. The input for this system is data. The nature of information manufacturing system is hierarchical in that information resulted in a certain stage can be considered as data for the next stage of the information manufacturing system. From this perspective, the term information can be used to refer to both data and information (Strong, Lee, \& Wang, 1997).

Moreover, information is a resource that should be properly managed throughout its lifecycle in order to get the full use and benefit from it. McGilvray (2008) wrote that the phases in information life cycle are:

1. Plan (P) - Preparing for the resource.

2. Obtain (O) - Acquiring the resource.

3. Store and share (S) - Holding information about the resources electronically or in hardcopy and share it through some type of distribution method.

4. Maintain (M) - Ensuring that the resource continues to work properly.

5. Apply (A) - Using the resources to accomplish goals.

6. Dispose (D) - Discarding the resource when it is no longer of use.

Those phases will be used later to define information management phases.

\section{Information Quality}

Today's organizations have information in many forms: records, texts, images, sounds, instructions, designs, blueprints, maps, metadata, detailed data, and summarized data. They have 
achieved quantity of data and information, but not necessarily quality of either, meaning that the data or information lacks one or more vital characteristics necessary for it to be fit for use (Pierce, 2005).

The quality of available information (the fitness for use of information) becomes a crucial factor for the effectiveness of organizations and individuals. But, issues of information quality problems in the organization are not identified until it is too late. Few organization treat information quality as a strategic issue, but they make strategic decisions with often inaccurate, incomplete and outdated data. There's however an emerging awareness that in the modern organization one is required to make decisions very quickly in order to gain information superiority and competitive advantage. High quality data is critical in such situations. Equally, many organizations are also painfully aware of the significant costs of poor quality data. Consequently, there is a growing demand for information quality initiatives as organizations' awareness of the importance of their information quality increases.

Some examples of information quality problems are described in Table 1.

Table 1. Information quality problems (Al-Hakim, 2007b)

\begin{tabular}{|c|c|c|}
\hline Problems & Reason & Information Phase \\
\hline $\begin{array}{l}\text { 1. Healthy - surgery } \\
\text { Two women with the same first } \\
\text { name attended a hospital in the same } \\
\text { day to have a breast biopsy. One had } \\
\text { breast cancer. One did not. The } \\
\text { woman with the breast cancer died } \\
\text { after nine months. }\end{array}$ & $\begin{array}{l}\text { It was discovered that the biopsy in- } \\
\text { formation results had been mixed up. } \\
\text { The woman with the breast cancer died } \\
\text { after nine months and the patient with- } \\
\text { out breast cancer had endured months } \\
\text { of chemotherapy and was minus a } \\
\text { breast (Pirani, 2004). }\end{array}$ & Plan \\
\hline $\begin{array}{l}\text { 2. Finance - share market } \\
\text { On } 9 \text { December } 2005 \text {, brokers at } \\
\text { Mizuho Securities tried to sell } \\
610,000 \text { shares at } 1 \text { yen ( } 0.8 \text { US } \\
\text { cents) each. The company had } \\
\text { meant to sell one share for } 610,000 \\
\text { yen -US } \$ 5,065 \text { ("Probe into Japan } \\
\text { share error," 2005). }\end{array}$ & $\begin{array}{l}\text { Mizuho said the brokerage had pur- } \\
\text { chased the majority of the phantom } \\
\text { shares it sold, but the error has so far } \\
\text { caused the company a loss of } 27 \text { bn yen } \\
\text { or US } \$ 21.6 \text { bn. } \\
\text { It is announced that this chaos into Ja- } \\
\text { pan market trading was a result of a } \\
\text { "typing error" ("Probe into Japan share } \\
\text { error," 2005), that is, problem in infor- } \\
\text { mation quality. }\end{array}$ & Obtain \\
\hline $\begin{array}{l}\text { 3. Media \& Mine Safety } \\
\text { On } 2 \text { January 2006, an explosion at } \\
\text { the Sago mine (West Virginia - } \\
\text { USA) trapped } 13 \text { workers. Shortly } \\
\text { before midnight in Tuesday, a } \\
\text { statement that } 12 \text { miners had been } \\
\text { found alive was made on several na- } \\
\text { tional TV stations and the broadcast } \\
\text { prompted jubilant scenes as friends } \\
\text { and relatives celebrated. But the eu- } \\
\text { phoria was short lived. Just hours af- } \\
\text { ter the banner headlines announced } \\
\text { that the } 12 \text { miners were safe, rescue } \\
\text { workers found their bodies ("Joy } \\
\text { turns to grief," } 2006 \text { ). }\end{array}$ & $\begin{array}{l}\text { Only one miner out of the } 13 \text { miners } \\
\text { survived. The sole survivor was taken } \\
\text { to the hospital where doctors said his } \\
\text { condition was critical. Ben Hatfield, } \\
\text { president of mine owner, International } \\
\text { Coal Group, blamed the earlier report } \\
\text { on "miscommunication." }\end{array}$ & Save and Store \\
\hline
\end{tabular}




\begin{tabular}{|c|c|c|}
\hline $\begin{array}{l}\text { 4. Space industry } \\
\text { The spacecraft launched by NASA } \\
\text { on } 11 \text { December } 1998 \text { to observe the } \\
\text { seasonal climate changes on Mars } \\
\text { was lost upon arrival at the planet on } \\
23 \text { September } 1999 \text {. }\end{array}$ & $\begin{array}{l}\text { It is found that the "root cause" of the } \\
\text { loss of the spacecraft was the "the } \\
\text { failed translation of English units into } \\
\text { metric units in a segment of ground- } \\
\text { based, navigation-related mission soft- } \\
\text { ware" (Isbell \& Savage, 1999). The IQ } \\
\text { problem here is the use of two different } \\
\text { types of information obtained from two } \\
\text { measurement systems. }\end{array}$ & Maintain \\
\hline $\begin{array}{l}\text { 5. Industry - refinery } \\
\text { On } 23 \text { March } 2005 \text { the BP Texas } \\
\text { City refinery in USA suffered a } \\
\text { huge blast. The blast claimed } 15 \\
\text { lives and injured } 170 \text { ("Errors led } \\
\text { to," 2005). }\end{array}$ & $\begin{array}{l}\text { The interim report into the tragedy has } \\
\text { found that failure to follow the proper } \\
\text { procedure (which is one type of infor- } \\
\text { mation) contributed to the explosion, } \\
\text { that is, IQ problem. }\end{array}$ & Apply \\
\hline $\begin{array}{l}\text { 6. Mine safety and health } \\
\text { On July 24, 2002, miners working } \\
\text { underground in the Quecreek coal } \\
\text { mine in Western Pennsylvania } \\
\text { (USA) accidentally broke into an } \\
\text { adjacent abandoned mine, which un- } \\
\text { leashed millions of gallons of water } \\
\text { and trapped nine men for three days. }\end{array}$ & $\begin{array}{l}\text { The report of the Mine Safety and } \\
\text { Health Administration (MSHA) (2003) } \\
\text { found that the primary cause of the } \\
\text { water inundation was use of un-dated } \\
\text { information obtained from old mine } \\
\text { map. }\end{array}$ & Disposal \\
\hline
\end{tabular}

Evans and Lindsay (2005) stress that quality can be a confusing concept, because people view quality using different perspectives and dimensions based on their individual roles, and the meaning of quality continues to evolve. Individuals have different wants and needs and, hence, different quality standards which lead to a user-based quality perspective.

One perspective of information criteria is proposed in COBIT 4.1, as follows:

- Effectiveness deals with information being relevant and pertinent to the business process as well as being delivered in a timely, correct, consistent and usable manner.

- Efficiency concerns the provision of information through the optimal (most productive and economical) use of resources.

- Confidentiality concerns the protection of sensitive information from unauthorized disclosure.

- Integrity relates to the accuracy and completeness of information as well as to its validity in accordance with business values and expectations.

- Availability relates to information being available when required by the business process now and in the future. It also concerns the safeguarding of necessary resources and associated capabilities.

- Compliance deals with complying with the laws, regulations contractual arrangements and format of the information to which the business process is subject, i.e., externally imposed business criteria as well as internal policies.

- Reliability relates to the timeliness and provision of appropriate information for management to operate the entity and exercise its fiduciary and governance responsibilities.

To satisfy business objectives, information needs to conform to those control criteria. 


\section{Maturity Model}

Obtaining an objective view of an enterprise's own performance level is not easy. What should be measured and how? Enterprises need to measure where they are and where improvement required, and implement a management tool kit to monitor this improvement.

Chrissis, Konrad, and Shrum, (2003) noted that a maturity level consists of related specific and generic practices for a predefined set of process areas that improve the organization's overall performance. The maturity level of an organization provides a way to predict an organization's performance in a given discipline or set of disciplines. Experience has shown that organizations do their best when they focus their process improvement efforts on a manageable number of process areas at a time and that those areas require increasing sophistication as the organization improves.

A maturity level is a defined evolutionary plateau for organizational process improvement. Each maturity level stabilizes an important part of the organization's processes, preparing it to move to the next maturity level. The maturity levels are measured by the achievement of the specific and generic goals associated with each predefined set of process areas.

There are five maturity levels, each a layer in the foundation for ongoing process improvement, designated by the numbers 1 through 5 :

0. Non-existent: Complete lack of any recognizable processes. The enterprise has not even recognized that there is an issue to be addressed.

1. Initial: There is evidence that the enterprise has recognized that the issues exist and need to be addressed. There are, however, no standardized processes; instead, there are ad hoc approaches that tend to be applied on an individual or case-by-case basis. The overall approach to management is disorganized.

2. Repetitive but intuitive: Processes have developed to the stage where similar procedures are followed by different people undertaking the same task. There is no formal training or communication of standard procedures, and responsibility is left to the individual. There is a high degree of reliance on the knowledge of individuals and, therefore, errors are likely to occur.

3. Defined: Procedures have been standardized and documented, and communicated through training. It is mandated that these processes should be followed; however, it is unlikely that deviations will be detected. The procedures themselves are not sophisticated but are the formalization of existing practices.

4. Managed and Measurable: Management monitors and measures compliance with procedures and takes action where processes appear not to be working effectively. Processes are under constant improvement and provide good practice. Automation and tools are used in a limited or fragmented way.

5. Optimized: Processes have been refined to a level of good practice, based on the results of continuous improvement and maturity modeling with other enterprises. IT is used in an integrated way to automate the workflow, providing tools to improve quality and effectiveness, making the enterprise quick to adapt.

Maturity levels are used to characterize organizational improvement relative to a set of process areas. This model is a way of measuring how well developed management processes are, i.e., how capable they actually are. How well developed or capable they should be primarily depends on the goals and the underlying business needs they support (IT Governance Institute, 2007).

The maturity models are built up starting from the generic qualitative model to which principles from the following attributes are added in an increasing manner through the levels: 
1. Awareness and communication (AC)

2. Policies, plans and procedures (PSP)

3. Tools and automation (TA)

4. Skills and expertise (SE)

5. Responsibility and accountability (RA)

6. Goal setting and measurement (GSM)

Maturity models provide a generic profile of the stages through which enterprises evolve for management and control of processes.

\section{Designing IQMM for Higher Education Institutions}

We design IQMM (Information Quality Maturity Model) by doing some steps as shown in Figure 2:

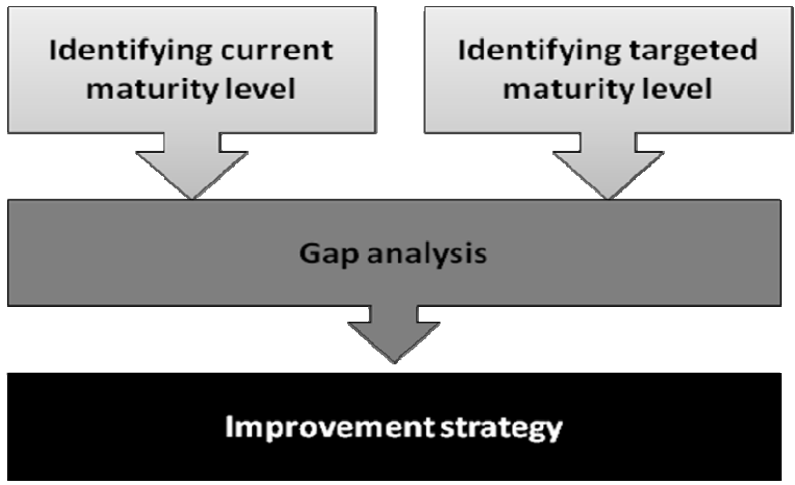

Figure 2. Design steps

\section{Design maturity level approach}

In general, there are two approaches in designing maturity level. The first approach, called vertical approach, is proposed by CMMI (Capability Maturity Model Integration), which design maturity level on vertical basis. Each level on CMMI described by process areas to be covered. Each process area has specific goals and generic goals, and described into specific practices and generic practices, respectively. This approach can be illustrated as shown in Figure 3:
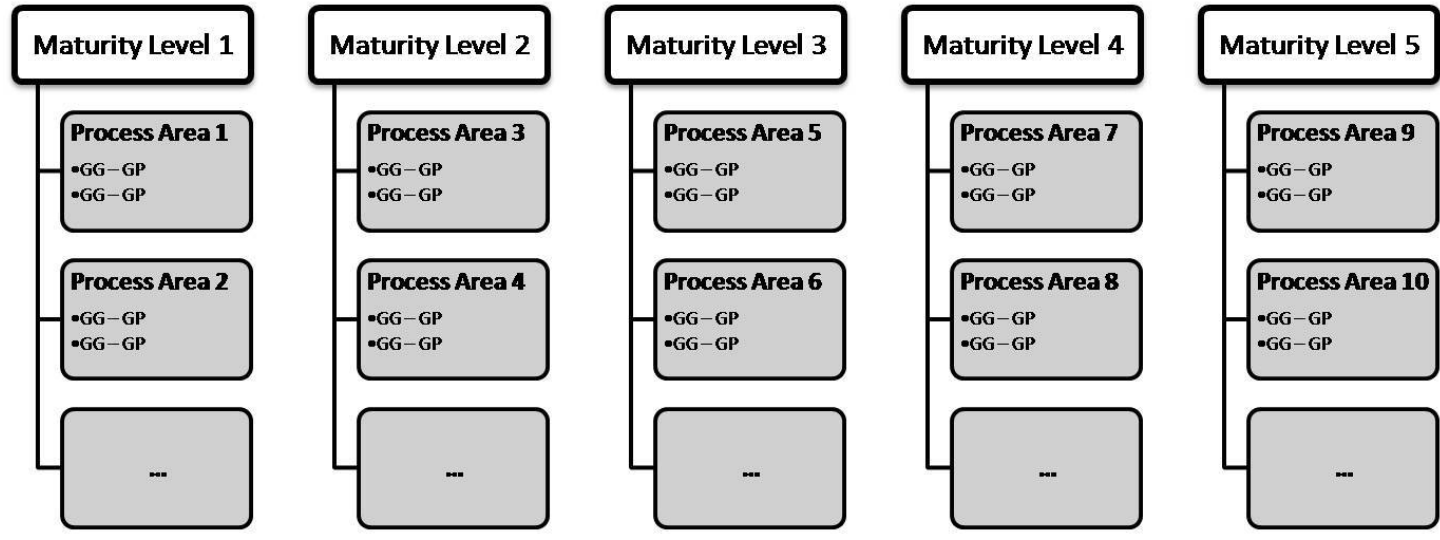

Figure 3. Vertical Approach on Maturity Model 
Another approach is proposed by COBIT 4.1, which horizontally defines maturity levels based on maturity attributes and phases in information life cycle. This horizontal approach has an advantage compared to the vertical one, which assure organizations to check each phase and each maturity attribute in assessing maturity level. The disadvantage is that by this approach, organization needs to spend more time to check maturity attributes for every phase they have. Horizontal approach can be illustrated as shown in Figure 4:

\begin{tabular}{l|c|c|c|c|c|c|}
\hline & Attr 1 & Attr 2 & Attr 3 & Attr 4 & Attr 5 & Attr 6 \\
\hline $\begin{array}{l}\text { Maturity } \\
\text { Level 1 }\end{array}$ & $\ldots$ & $\ldots$ & $\ldots$ & $\ldots$ & $\ldots$ & $\ldots$ \\
\hline $\begin{array}{l}\text { Maturity } \\
\text { Level 2 }\end{array}$ & $\ldots$ & $\ldots$ & $\ldots$ & $\ldots$ & $\ldots$ & $\ldots$ \\
\hline $\begin{array}{l}\text { Maturity } \\
\text { Level 3 }\end{array}$ & $\ldots$ & $\ldots$ & $\ldots$ & $\ldots$ & $\ldots$ & $\ldots$ \\
\hline $\begin{array}{l}\text { Maturity } \\
\text { Level 4 }\end{array}$ & $\ldots$ & $\ldots$ & $\ldots$ & $\ldots$ & $\ldots$ & $\ldots$ \\
\hline $\begin{array}{l}\text { Maturity } \\
\text { Level 5 }\end{array}$ & $\ldots$ & $\ldots$ & $\ldots$ & $\ldots$ & $\ldots$ & $\ldots$ \\
\hline
\end{tabular}

Figure 4. Horizontal Approach on Maturity Model

\section{Maturity Model Design}

We design maturity model for information quality based on COBIT 4.1 approach. COBIT 4.1 has been defined the mapping of maturity attributes into maturity levels. We implement it to assess each phase in Information Life Cycle. The model resulted are shown in Table 2:

Table 2. Maturity Model (adapted from IT Governance Institute, 2007)

\begin{tabular}{|l|ll|}
\hline Maturity Level & \multicolumn{1}{c|}{ Description } \\
\hline 7. Initial & $\begin{array}{l}\text { Recognition of the need in information lifecycle phases is emerging. } \\
\text { There is sporadic communication of the issues. (AC) }\end{array}$ \\
- $\begin{array}{l}\text { There are ad hoc approaches to process and practices in information life- } \\
\text { cycle phases. The process and policies are undefined. (PSP) }\end{array}$ \\
- $\begin{array}{l}\text { Some tools may exist in information lifecycle phase's usage are based on } \\
\text { standard desktop tools. There is no planned approach to the tools usage. } \\
\text { (TA) }\end{array}$ \\
$\begin{array}{l}\text { Skills required to information lifecycle phases are not identified. A train- } \\
\text { ing plan does not exist and no formal training occurs. (SE) }\end{array}$ \\
- $\begin{array}{l}\text { There is no definition of accountability and responsibility in information } \\
\text { lifecycle phases. People take ownership of issues based on their own ini- } \\
\text { tiative on a reactive basis. (GSM) }\end{array}$ \\
\hline
\end{tabular}




\begin{tabular}{|c|c|}
\hline $\begin{array}{l}\text { 8. } \begin{array}{l}\text { Repetitive } \\
\text { but intuitive }\end{array}\end{array}$ & $\begin{array}{l}\text { - There is awareness of the need to act on information lifecycle phases. } \\
\text { Management communicates the overall issues. (AC) } \\
\text { - Similar and common processes emerge on information lifecycle phases } \\
\text { but are largely intuitive because of individual expertise. Some aspects of } \\
\text { the process are repeatable because of individual expertise, and some do- } \\
\text { cumentation and informal understanding of policy and procedures may } \\
\text { exist. (PSP) } \\
\text { - Common approaches to use of information lifecycle phase's tools exist } \\
\text { but are based on solutions developed by key individuals. Vendor tools } \\
\text { may have been acquired, but are probably not applied correctly, and may } \\
\text { even be shelf ware. (TA) } \\
\text { Minimum skill requirements are identified for critical areas on informa- } \\
\text { tion lifecycle phases. Training is provided in response to needs, rather } \\
\text { than on the basis of an agreed plan, and informal training on the job oc- } \\
\text { curs. (SE) } \\
\text { An individual assumes his/ her responsibility in information lifecycle } \\
\text { phases and is usually held accountable, even if this is not formally } \\
\text { agreed. There is confusion about responsibility when problems occur, } \\
\text { and a culture of blame tends to exist. (RA) } \\
\text { Some goal setting occurs in information lifecycle phases, some financial } \\
\text { measures are established but are known only by senior management. } \\
\text { There is inconsistent monitoring in isolated areas. (GSM) }\end{array}$ \\
\hline 3. Defined & $\begin{array}{l}\text { There is understanding of the need to act on information lifecycle phas- } \\
\text { es. Management is more formal and structured in its communication. } \\
\text { (AC) } \\
\text { - Usage of good practices emerges. The process, policies and procedures } \\
\text { for information lifecycle phases are defined and documented for all key } \\
\text { activities. (PSP) } \\
\text { - A plan has been defined for use and standardization of tools to automate } \\
\text { information lifecycle phases. Tools are being used for their basic pur- } \\
\text { poses, but may not all be in accordance with the agreed plan, and may } \\
\text { not be integrated with one another. (TA) } \\
\text { - Skill requirements are defined and documented for information lifecycle } \\
\text { phases in all areas. A formal training plan has been developed, but for- } \\
\text { mal training is still based on individual initiatives. (SE) } \\
\text { Information lifecycle phases responsibility and accountability are de- } \\
\text { fined and process owners have been identified. The process owner is un- } \\
\text { likely to have the full authority to exercise the responsibilities. (RA) } \\
\text { - Some effectiveness goals and measures are set for information lifecycle } \\
\text { phases, but are not communicated, and there is a clear link to business } \\
\text { goals. Measurement processes emerge, but are not consistently applied. } \\
\text { IT balanced scorecard ideas are being adopted, as is occasional intuitive } \\
\text { application of root cause analysis. (GSM) }\end{array}$ \\
\hline
\end{tabular}




\begin{tabular}{|c|c|}
\hline $\begin{array}{l}\text { 2. Managed } \\
\text { and measur- } \\
\text { able }\end{array}$ & $\begin{array}{l}\text { - There is understanding of the full requirements on information lifecycle } \\
\text { phases. Mature communication techniques are applied and standard } \\
\text { communication tools are in use. (AC) } \\
\text { The information lifecycle phases are sound and complete; internal best } \\
\text { practices are applied. All aspects of information lifecycle phases are do- } \\
\text { cumented and repeatable. (PSP) } \\
\text { Tools are implemented on information lifecycle phases according to a } \\
\text { standardized plan, and some have been integrated with other related } \\
\text { tools. Tools are being used in main areas to automate management of the } \\
\text { processes and monitor critical activities and controls. (TA) } \\
\text { - Skill requirements on information lifecycle phases are routinely updated } \\
\text { for all areas, proficiency is ensured for all critical areas, and certification } \\
\text { is encouraged. Mature training techniques are applied according to the } \\
\text { training plan, and knowledge sharing is encouraged. All internal domain } \\
\text { experts are involved, and the effectiveness of the training plan is as- } \\
\text { sessed. (SE) } \\
\text { Information lifecycle phases responsibility and accountability are ac- } \\
\text { cepted and working in a way that enables a process owner to fully dis- } \\
\text { charge his/ her responsibilities. A reward culture is in place that moti- } \\
\text { vates positive action. (RA) } \\
\text { Efficiency and effectiveness on information lifecycle phases are meas- } \\
\text { ured and communicated and linked to business goals and the IT strategic } \\
\text { plan. The IT BSC is implemented in some areas with exceptions noted } \\
\text { by management and root cause analysis is being standardized. Continu- } \\
\text { ous improvement is emerging. (GSM) }\end{array}$ \\
\hline
\end{tabular}




\begin{tabular}{|c|c|}
\hline 3. Optimize & $\begin{array}{l}\text { There is advanced, forward-looking understanding of requirements on } \\
\text { information lifecycle phases. Proactive communication of issues based } \\
\text { on trends exists, mature communication techniques are applied, and inte- } \\
\text { grated communication tools are in use. (AC) } \\
\text { External best practices and standards are applied on information lifecycle } \\
\text { phases. Process documentation is evolved to automated workflows. } \\
\text { Processes, policies and procedures are standardized and integrated to en- } \\
\text { able end-to-end management and improvement. (PSP) } \\
\text { - Standardized tool sets are used across the enterprise on information life- } \\
\text { cycle phases. Tools are fully integrated with other related tools to enable } \\
\text { end-to-end support of the processes. Tools are being used to support im- } \\
\text { provement of the process and automatically detect control exceptions. } \\
\text { (TA) } \\
\text { The organization formally encourages continuous improvement of skills, } \\
\text { based on clearly defined personal and organizational goals on informa- } \\
\text { tion lifecycle phases. Training and education support external best prac- } \\
\text { tices and use of leading-edge concepts and techniques. Knowledge shar- } \\
\text { ing is an enterprise culture, and knowledge-based systems are being de- } \\
\text { ployed. External experts and industry leaders are used for guidance. (SE) } \\
\text { Process owners are empowered to make decisions and take action on in- } \\
\text { formation lifecycle phases. The acceptance of responsibility has been } \\
\text { cascaded down throughout the organization in a consistent fashion. (RA) } \\
\text { There is an integrated performance measurement system linking IT per- } \\
\text { formance to business goals by global application of the IT BSC on in- } \\
\text { formation lifecycle phases. Exceptions are globally and consistently } \\
\text { noted by management and root-cause analysis is applied. Continuous } \\
\text { improvement is a way of life. }\end{array}$ \\
\hline
\end{tabular}

\section{Maturity Model Implementation Scenario}

For implementing maturity model designed, below are steps to do.

1. Create a map on information processes into RACI chart, which defines people who are responsible (R), accountable (A), consulted(C), and informed (I) related to each phase in information life cycle. This chart is as introduced in COBIT 4.1 (ITGI, 2007) to map roles on processes related to information management. Figure 5 is an example of RACI chart about academic information process which maps roles in the organization into phases in information lifecycle: 


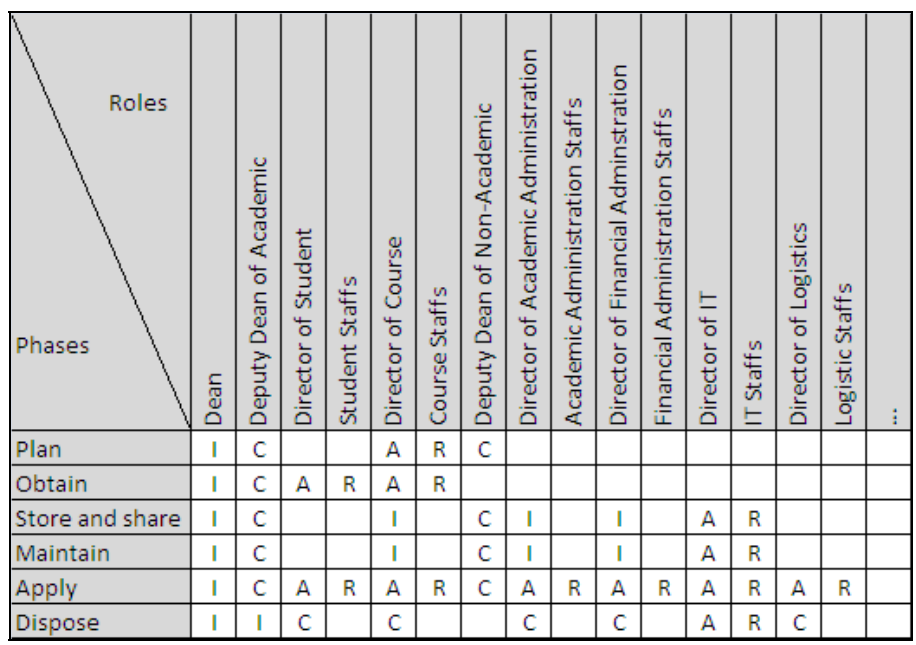

Figure 5. Example of RACI Chart

Phases in information life cycle can be described based on actual processes in an organization, thus may create more rows in the RACI chart.

2. Choose people to survey. People involved in a process are the ones who understand exactly about the quality of the process. RACI chart resulted can be used as reference to choose people surveyed. All respondents will have to answer same questions about maturity level of each phase of information lifecycle. By doing this, respondents will give answer based on their own quality perspective.

From this example, 15 roles are related with phases in information lifecycle and should be surveyed to define information quality maturity level. There can be done some sampling techniques to decrease the number of respondents being surveyed in this step.

3. Conduct survey to define current and targeted maturity level. Based on maturity model designed, run a survey on people chosen in organization. The IQMM is asked twice, each to define current maturity level and targeted maturity level. The gap between those two levels can be used as guideline for improvement plan.

For example, the results of the survey are illustrated as radar diagram on Figure 6.

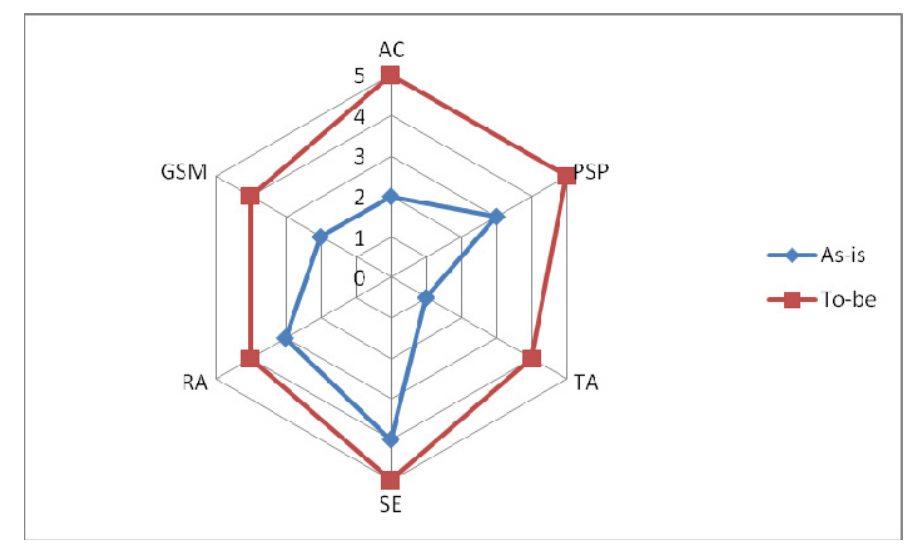

Figure 6. Survey result's radar diagram

Radar diagram in Figure 6 shows that:

a. awareness and communication attribute (AC) is at maturity level 2 and targeted to reach level $5(\mathrm{gap}=3)$, 
b. policies, standard, and procedures attribute (PSP) is at maturity level 3 and targeted to reach level $5($ gap $=2)$,

c. tools and automation attribute (TA) is at maturity level 1 and targeted to reach level $4($ gap $=3)$,

d. skills and expertise attribute (SE) is at maturity level 4 and targeted to reach level $5($ gap $=1)$,

e. responsibility and accountability attribute (RA) is at maturity level 3 and targeted to reach level $4(\mathrm{gap}=1)$,

f. goal setting and measurement (GSM) is at maturity level 2 and targeted to reach level $4($ gap $=2)$.

This survey result can be used to define the improvement plans as explain in the next step.

\section{Define the improvement plans}

Based in the survey result, the organization can define the improvement plans by prioritizing attributes with a higher gap between as-is and to-be maturity level. From the result above, we can define improvement plan as follow:

First priority $(\mathrm{gap}=3)$ :

a. AC, can be improved by facilitating structured communication among organization's members so that they aware of the important of information management.

b. TA, can be improved by implementing an integrated tools to automate processes of information management.

Second priority $($ gap $=2)$ :

a. PSP, can be improved by periodically monitors and revises policies, standards, and procedures of information management in all business units.

b. GSM, can be improved by setting a structure goal of each information management process and implementing a standard measurement.

Third priority $(\mathrm{gap}=1)$ :

a. SE, can be improved by continuously monitors and improves members' skills and expertise through a structured training and practice.

b. RA, can be improved by implementing reward and punishment.

\section{Conclusion}

IQMM is built using horizontal approach, which is expanding maturity model defined by CMM based on maturity attributes defined by COBIT 4.1. By using this model, organizations can understand their current and targeted condition represented by maturity level. That understanding can be used to define improvement strategy on information management. Current and targeted maturity level is gathered by survey on people involved in each phase of information life cycle. The challenge in doing this is how to choose the correct respondents who have a good perspective of information quality. The next result is proposed improvement plan, which can be obtained by analyzing the gap between current and targeted maturity level.

A further research can be done to improve this model by considering information quality criteria targeted by organization. This consideration can give a more detailed action to be done as the improvement plan of information management in an organization. Another improvement of this re- 
search can be done by analyzing maturity level gap of each information lifecycle phases of an organization. By doing this, improvement plan can be defined based on phases' priorities.

\section{References}

Al-Hakim, L. (2007a). Information quality management: Theories and applications. University of Southern Queensland, Australia: IDEA Group Publishing.

Al-Hakim, L. (2007b). Challenges of managing information quality in service organizations. University of Southern Queensland, Australia: Idea Group Publishing.

Ballou, D., Wang, R., Pazer, H., \& Tayi, H. (1998). Modeling information manufacturing systems to determine information product quality. Management Science, 44(4), 462-484.

Chrissis, M. B., Konrad, M., \& Shrum, S. (2003). CMMI: Guidelines for process integration and product improvement. Addison-Wesley.

Errors led to BP refinery blast. (2005, May 17). BBC News. Available online on http://news.bbc.co.uk/2/hi/business/4557201.stm

Evans, J. R., \& Lindsay, W. M. (2005). The management and control of quality (6th ed.). Cincinnati, OH: South-Western, Thomson Learning.

Huang, K-T., Lee, Y.W., \& Wang, R.Y. (1999). Quality information and knowledge. NJ: Prentice-Hall PTR.

Isbell, D., \& Savage, D. (1999). Mars climate orbiter failure board releases report: Numerous NASA actions underway in response. SpaceRef.Com. Available online at http://www.spaceref.com:16080/news/viewpr.html?pid=43

IT Governance Institute. (2007). COBIT 4.1: Framework, Control Objectives, Management Guidelines, Maturity Models.

Joy turns to grief for trapped miners' families. (2006, January 5). South China Morning Post, LX11(5). Hong Kong: Associated Press.

McGilvray, D. (2008). Executing data quality projects: Ten steps to quality data and trusted information. Morgan Kaufman.

MSHA. (2003). MSHA issues Quecreek investigation report. U. S. Department of Labor: Mine Safety and Health Administration. Available at http://www.msha.gov/Media/PRESS/2003/NR030812.htm

Pierce, E. M. (2005). Introduction. In R. Wang, E. Pierce, S. Madnick \& C. Fisher (Eds.), Information quality (pp. 3-17). Advances in Management Information System, 1. Armonk, NY: M. E. Sharpe.

Pirani, C. (2004, January 24-25). How safe are our hospitals? The Weekend Australian.

Probe into Japan share error. (2005, December 9). BBC News. Available online on http://news.bbc.co.uk/2/hi/business/4512962.stm

Strong, D. M., Lee, Y. W., \& Wang, R. Y. (1997). Data quality on context. Communications of the ACM, 40(5), 103-110.

Wang, R. Y., Pierce, E. M., Madnick, S. E., \& Fisher, C. W. (2005). Information quality. Advances in Management Information Systems (AMIS). Armonk, New York and London, England: M.E. Sharpe. 


\section{Biographies}

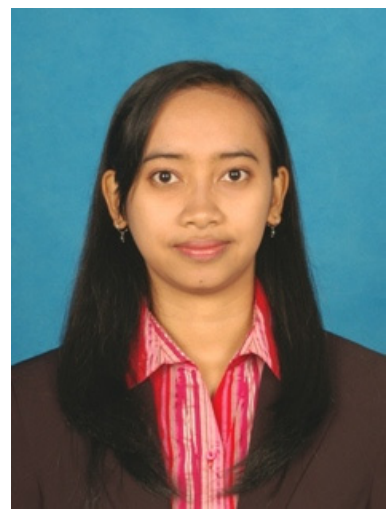

Angelina Prima Kurniati, ST., MT. is a faculty of Informatics Faculty at Telkom Institute of Technology. She is usually teaching about Human and Computer Interaction, Data Mining, Information System Management, and Information System Project Management. While finishing her Master degree at Bandung Institute of Technology (ITB), she was doing a research about Information Quality Management.

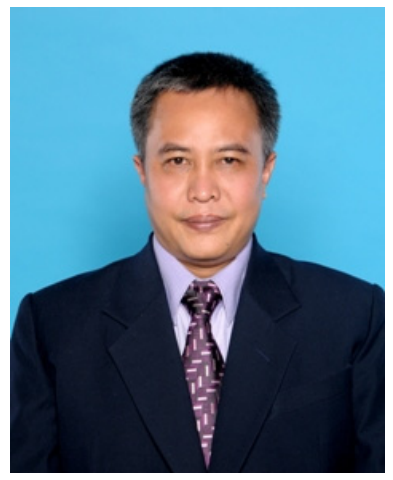

Dr. Kridanto Surendro, M.Sc., Ph.D is a faculty of School of Electronics and Informatics at Bandung Institute of Technology (ITB). As the head of Information System Laboratory, he leads some researchs in Information System, Information Technology Governance, Information Technology and Information System Management. 